\title{
Perbedaan Kemampuan Spasial dan Disposisi Matematik Siswa yang Diajar Melalui Pendekatan Penemuan Terbimbing Berbantuan Cabri 3-D
}

\author{
Togi A Napitupulu ${ }^{1}$, Mangaratua M Simanjorang ${ }^{2}$, Mulyono ${ }^{3}$ \\ 1,2,3 Prodi Pendidikan Matematika Pascasarjana, Universitas Negeri Medan \\ Universitas Negeri Medan, Jalan William IskandarPasar V, Medan, Indonesia \\ toginapitupulu.tn@gmail.com
}

\begin{abstract}
This study aims to: 1) find out the significant differences in students' spatial abilities and analyze the differences in students' spatial abilities between students who were taught using a guided discovery approach assisted by Cabri 3D Software and expository method assisted by Cabri 3D Software; 2) to find out the significant differences in students' mathematical dispositions and to analyze the differences in mathematical dispositions between students who were taught using a guided discovery approach assisted by Cabri 3D Software and an expository method assisted by Cabri 3D Software. This study also uses mixed method research which combines quantitative research and qualitative research. This research was carried out at SMA Negeri 1 Medan in the first semester, October 3rd week of the 2020/2021 academic year. The results showed that 1) There were differences in the mathematical spatial abilities of students who were taught through a guided discovery approach assisted by Cabri 3D Software and students who were taught through an expository method assisted by Cabri 3D Software; 2) There are differences in the mathematical disposition of students who are taught through a guided discovery approach assisted by Cabri 3D Software and students who are taught through an expository method assisted by Cabri 3D Software.
\end{abstract}

Keywords: Spatial Ability, Mathematical Disposition, Guided Discovery, Cabri 3D

\begin{abstract}
Abstrak
Penelitian ini bertujuan untuk : 1) mengetahui perbedaan kemampuan spasial siswa antara siswa yang diajar menggunakan pendekatan penemuan terbimbing berbantuan Software Cabri 3D dengan metode ekspositori berbantuan Software Cabri 3D;2) mengetahui perbedaan disposisi matematik siswa yang diajar menggunakan pendekatan penemuan terbimbing berbantuan Software Cabri 3D dengan metode ekspositori berbantuan Software Cabri 3D. Penelitian ini juga menggunakan mixed method research dimana menggabungkan antara penelitian kuantitatif dan penelitian kualitatif. Penelitian ini telah dilaksanakan di SMA Negeri 1 Medan pada semester I, bulan Oktober minggu ke 3 tahun pelajaran 2020/2021. Hasil penelitian menunjukkan bahwa 1) Terdapat perbedaan kemampuan spasial matematik siswa yang diajar melalui pendekatan penemuan terbimbing berbantuan Software Cabri $3 D$ dengan siswa yang diajar melalui metode ekspositori berbantuan Software Cabri 3D; 2) Terdapat perbedaan disposisi matematik siswa yang diajar melaluipendekatan penemuan terbimbing berbantuan Software Cabri 3D dengan siswa yang diajar melalui metode ekspositori berbantuan Software Cabri 3D. Pembelajaran dengan pendekatan penemuan terbimbing berbantuan SoftwareCabri 3D pada pembelajaran matematika yang menekankan kemampuan spasial matematik dan disposisi matematik siswa, sehingga dapat dijadikan sebagai salah satu alternatif untuk menerapkan pembelajaran matematika yang inovatif.
\end{abstract}

Kata kunci: Kemampuan Spasial, Disposisi Matematik, Penemuan Terbimbing, Cabri 3D

Copyright (c) 2022 Togi A Napitupulu, Mangaratua M Simanjorang, Mulyono

$\triangle$ Corresponding author: Togi A Napitupulu

Email Address: toginapitupulu.tn@ gmail.com (Jalan William Iskandar Pasar V, Medan, Indonesia)

Received 09 January 2022, Accepted 07 February 2022, Published 08 February 2022

\section{PENDAHULUAN}

Pendidikan adalah salah satu bentuk perwujudan kebudayaan manusia yang dinamis dan sarat perkembangan (Trianto., 2011). Pendidikan yang mampu mendukung pembangunan di masa mendatang adalah pendidikan yang mampu mengembangkan potensi siswa, sehingga siswa mampu menghadapi dan memecahkan persoalan kehidupan yang dihadapinya. Oleh karena itu, perlu pembekalan kemampuan kepada siswa berupa mata pelajaran dengan beberapa disiplin ilmu yang 
harus dikuasai. Pada kurikulum 2013, mata pelajaran yang diberikan pada jenjang sekolah menengah atas terdiri dari dua bagian yaitu mata pelajaran wajib dan pilihan (Kemendikbud, 2012). Salah satu mata pelajaran wajib yang harus dikuasai siswa adalah matematika.

Sebagai suatu disiplin ilmu, matematika memiliki tujuan pembelajaran. Adapun tujuan pembelajaran matematika agar peserta didik memiliki kemampuan; (1) memahami konsep matematika, menjelaskan keterkaitan antar konsep dan mengaplikasikan konsep atau algoritma, secara luwes, akurat, efisien, dan tepat, dalam pemecahan masalah; (2) menggunakan penalaran pada pola dan sifat, melakukan manipulasi matematika dalam membuat generalisasi, menyusun bukti, atau menjelaskan gagasan dan pernyataan matematika; (3) memecahkan masalah yang meliputi kemampuan memahami masalah, merancang model matematika, menyelesaikan model dan menafsirkan solusi yang diperoleh; (4) mengkomunikasikan gagasan dengan simbol, tabel, diagram, atau media lain untuk memperjelas keadaan atau masalah; (5) memiliki sikap menghargai kegunaan matematika dalam kehidupan, yaitu memiliki rasa ingin tahu, perhatian, dan minat dalam mempelajari matematika, serta sikap ulet dan percaya diri dalam pemecahan masalah (Depdiknas, 2013).

Tujuan pembelajaran tersebut akan dicapai melalui proses pembelajaran matematika. Proses pembelajaran matematika melibatkan lima standar isi yaitu konsep dan operasi bilangan, pengukuran, geometri, aljabar serta analisis data dan peluang (NCTM, 2013). Kelima standar isi ini kemudian akan dipartisi menjadi beberapa pokok bahasan serta sub pokok bahasan yang akan dipelajari siswa di berbagai jenjang pendidikan. Geometri sendiri sebagai salah satu ruang lingkup materi pembelajaran matematika juga telah dibagi menjadi beberapa pokok bahasan yang dipelajari di setiap jenjang pendidikan dengan tingkat kesulitan yang disesuaikan dengan tingkat perkembangan kognitif siswa. Untuk itu diperlukan pemahaman keruangan yang bagus agar siswa bisa memahami dimensi geometri ruang tersebut. Pemahaman keruangan itu dikenal dengan kemampuan spasial. Menurut Piaget dan Inhelder (Tambunan, 2006) menyebutkan bahwa kemampuan berpikir spasial adalah suatu kemampuan mengamati hubungan posisi objek dalam ruang, kemampuan untuk melihat objek dari berbagai sudut pandang, kemampuan untuk memperkirakan jarak antara dua titik, serta kemampuan lainnya yang berkaitan dengan bangun ruang.

Dari beberapa hasil penelitian yang telah dikemukakan, terdapatlah suatu hubungan positif antara kemampuan spasial yang dimiliki siswa dengan penguasaan siswa terhadap matematika. Jika proses peningkatan kemampuan spasial siswa terus berlangsung maka hal ini akan berbanding lurus dengan peningkatan penguasaan siswa terhadap matematika. Akibat selanjutnya yang diperoleh yaitu hasil belajar matematika siswa akan sangat memuaskan. Inilah yang juga menjadi alasan pentingnya kemampuan berpikir spasial, yaitunya agar penguasaan siswa terhadap matematika juga semakin meningkat.

Beberapa pernyataan di atas menyatakan betapa pentingnya kemampuan spasial dikuasai oleh siswa, akan tetapi kenyataan di lapangan sangat berlawanan dengan apa yang diharapkan. Pada kenyataannya, kemampuan spasial siswa masih tergolong rendah dan bermasalah. Fauzan (Syarah, 
2013) menyatakan bahwa kemampuan spasial yang dimiliki oleh siswa kelas X SMA di Sumatera Barat masih rendah. Ada beberapa hal yang ditemukan dalam penelitiannya, yaitu siswa terfokus pada tampilan-tampilan yang berupa gambar, siswa membutuhkan alat peraga yang berkaitan dengan materi yang dipelajari dan siswa tidak menguasai konsep-konsep geometri dasar.

Kemampuan spasial matematika yang rendah ini juga terlihat pada hasil analisis daya serap Ujian Nasional materi pokok dimensi tiga yang masih tergolong rendah. Ditemukan bahwa siswa SMA N 1 Banjarnegara tahun 2011 sebesar 79,83 \%, untuk Kabupaten Banjarnegara sebesar 51,52\%, untuk Propinsi Jawa Tengah sebesar 52,96\% dan untuk Nasional sebesar 64,78\% (Pranawestu dkk, 2012:2).

Berdasarkan kurikulum 2013, standar kompetensi untuk satuan pendidikan SMP, materi geometri memiliki porsi yang paling besar (41\%) dibandingkan dengan materi lain seperti aljabar (29\%) bilangan (18\%), serta statistika dan peluang (12\%). Paling banyaknya persentase pengajaran geometri tersebut sehingga geometri menempati posisi khusus dalam kurikulum matematika. Geometri pada dasarnya berpeluang lebih besar untuk dipahami siswa dibandingkan dengan cabang matematika lainnya, karena geometri sangat dekat dengan kehidupan sehari-hari. Begitu luasnya cakupan geometri baik itu dalam kehidupan sehari-hari maupun dalam kurikulum sekolah tetapi tingkat penguasaan siswa dalam geometri masih rendah, yang dapt terlihat dari beberapa perlombaan siswa Indonesia ditingkat dunia menunjukan bahwa siswa lemah dalam geometri khususnya dalam ruang dan bentuk. Sholihah \& Afriansyah (Sholihah \& Afriansyah, 2018) menyatakan bahwa di Indonesia banyak siswa yang ditemukan mengalami kesulitan dalam belajar geometri.

Selain kemampuan spasial dalam matematika, diperlukan juga adanya rasa sungguh-sungguh dan ketertarikan terhadap matematika. Di dalam matematika ini disebut disposisi matematis. Fakta rendahnya ketertarikan siswa terhadap matematika pada siswa SMP peringkat tinggi, sedang, dan rendah sebanyak 297 orang di kota Palembang. Hasil studi menunjukkan persentase skor rata-rata disposisi matematis siswa baru mencapai 58 persen yang diklasifikasikan rendah. Dari penelitian ini dapat disimpulkan rata-rata disposisi matematis siswa di Indonesia belum menggembirakan.

Rendahnya kemampuan spasial dan disposisi matematiksiswa yang merupakan suatu hasil belajar, sangat dipengaruhi oleh beberapa hal. Menurut Slameto (Slameto, 2010) faktor-faktor yang mempengaruhi hasil belajar siswa dibedakan menjadi 2 jenis, yaitu faktor internal dan faktor eksternal.

Menurut Khulthau (Kuhlthau \& Todd, 2007) penemuan terbimbing adalah pendekatan pembelajaran dimana siswa menemukan dan menggunakan berbagai sumber informasi dan ide-ide untuk meningkatkan pemahaman mereka mengenai suatu permasalahan, topik dan isu. Sedangkan Mulyasa (Hamzah \& Muhlisrarini, 2014) metode penemuan terbimbing adalah metode yang mampu menggiring peserta didik untuk menyadari apa yang telah didapatkan selama belajar. Penemuan terbimbing menempatkan peserta didik sebagai subjek belajar yang aktif. 
Dalam kurikulum 2013 sendiri penggunaan teknologi dalam pembelajaran menjadi sesuatu yang sangat dianjurkan. Proses pembelajaran pada kurikulum 2013 menuntut siswa untuk berpartisipasi aktif serta memberi ruang yang cukup untuk kreativitas, minat dan bakat siswa. Teknologi pun menjadi sorotan utama dalam kurikulum 2013, hal ini terdapat didalam Permendiknas No. 65 tentang Standar Proses bahwa pembelajaran memanfaatkan teknologi informasi dan komunikasi untuk meningkatkan efisiensi dan efektivitas pembelajaran.

Pembelajaran dengan Cabri 3D dapat membantu siswa mengamati objek-objek abstrak dalam geometri dan menjadikannya terlihat lebih nyata. Melalui Software Cabri 3D ini siswa juga akan lebih mudah memahami konsep dan hubungan yang terdapat di dalam suatu dimensi tiga. Adanya penggunaan Software Cabri 3D ini tentunya akan melatih dan mengasah kemampuan spasial siswa, sehingga mengakibatkan kemampuan spasial mengalami peningkatan menjadi lebih bagus. Selanjutnya, bagusnya kemampuan spasial siswa membuat siswa semakin percaya diri ketika menyelesaikan permasalahan dimensi tiga. Siswa akan berusaha menyelesaikan permasalahan tersebut dengan segala kemampuan yang dimilikinya. Bahkan masalah yang sulit pun bukan menjadi sesuatu hal yang menakutkan akan tetapi menjadi suatu tantangan bagi siswa, karena siswa itu memiliki kemampuan untuk menyelesaikan permasalahan itu. Hal ini secara tidak langsung akan menyebabkan meningkatnya kemampuan disposisi matematik siswa.

Kemampuan spasial dan disposisi matematik siswa dalam pembelajaran mengalami beberapa kesulitan karena peserta didik kurang terlatih dalam mengembangkan ide-idenya di dalam memecahkan masalah. Selain itu, peserta didik juga kurang percaya diri dan tidak berani mengemukakan pendapat. Untuk mengatasi permasalahan tersebut, diperlukan suatu pendekatan pembelajaran yang tepat dan menarik, dimana peserta didik dapat belajar secara aktif untuk menyelesaikan soal dengan berbagai cara, yaitu dengan menggunakan pembelajaran metode ekspositori dan pendekatan penemuan terbimbingberbantuan software Cabri $3 D$. Dalam pelaksanaan pembelajaran nya peneliti mencoba melihat menganasisa perbedaaan dari pendekatan penemuan terbimbing dan pembelajaran langsung dengan berbasis ICT.

\section{METODE}

Pembelajaran dengan Cabri 3D dapat membantu siswa mengamati objek-objek abstrak dalam geometri dan menjadikannya terlihat lebih nyata. Melalui Software Cabri $3 D$ ini siswa juga akan lebih mudah memahami konsep dan hubungan yang terdapat di dalam suatu dimensi tiga. Adanya penggunaan Software Cabri 3D ini tentunya akan melatih dan mengasah kemampuan spasial siswa, sehingga mengakibatkan kemampuan spasial mengalami peningkatan menjadi lebih bagus. Selanjutnya, bagusnya kemampuan spasial siswa membuat siswa semakin percaya diri ketika menyelesaikan permasalahan dimensi tiga. Siswa akan berusaha menyelesaikan permasalahan tersebut dengan segala kemampuan yang dimilikinya. Bahkan masalah yang sulit pun bukan menjadi sesuatu hal yang menakutkan akan tetapi menjadi suatu tantangan bagi siswa, karena siswa itu memiliki 
kemampuan untuk menyelesaikan permasalahan itu. Hal ini secara tidak langsung akan menyebabkan meningkatnya kemampuan disposisi matematiksiswa.

Penelitian ini telah dilaksanakan di SMA Negeri 1 Medan pada semester I, bulan Oktober minggu ke 3 tahun pelajaran 2020/2021. Pelaksanaannya berlangsung selama 6 kali pertemuan (12 jam pelajaran $=12 \times 45$ menit) untuk kedua kelas sampel.

Instrumen penelitian yang digunakan dalam penelitian ini ada 2 jenis yaitu tes dan angket. Bentuk tes yang dikembangkan untuk mengukur kemampuan spasial siswa pada materi yang disajikan sesuai indikator yang ingin dicapai dalam sedangkan angket untuk mengukur disposisi matematik siswa.

\section{Tes Kemampuan Spasial}

Tes kemampuan spasial siswa dilakukan untuk mengetahui peningkatan kemampuan spasial siswa. Tes kemampuan spasial ini disusun berbentuk uraian yang terdiri dari 4 butir soal. Pemberian skor dalam mengukur kemampuan spasial menggunakan skala bebas, bergantung pada besarnya bobot butir soal tersebut.

\section{Instrumen Disposisi Matematik}

Instrumen ini berguna untuk menjaring data disposisi matematik siswa. Bentuk instrumen ini adalah angket sejumlah 24 pertanyaan yang menggunakan model skala sikap yaitu model skala sikap Likert.

Berdasarkan pertanyaan nomor satu dan dua pada rumusan masalah, maka data pretes dan postes akan dianalisis dengan statistik inferensial anakova. Analisis infernesial ini digunakan untuk menguji hipotesis dalam penelitian ini. Penggunaan anakova dalam penelitian ini karena penelitian ini membandingkan perbedaan variabel terikat dengan varibael bebas sekaligus menghubungkan varibel terikat tersebut terhadap varibel lainnya dalam hal ini adalah varibel penyerta. Data yang akan dianalisis dalam penelitian ini adalah pretes (kemampuan awal siswa) sebagai variabel penyerta dan postes (kemampuan akhir) sebagai variabel terikat.

\section{HASIL DAN DISKUSI}

\section{Hasil Pretes Kemampuan Spasial}

Secara kuantitatif, pretes kemampuan spasial disajikan pada Tabel 2. dan Tabel 3.

Tabel 2. PretesKemampuan Spasial Siswa KelasPendekatan Penemuan Terbimbing BerbantuanSoftwareCabri3D (Eksperimen 1) Secara Kuantitatif

\begin{tabular}{|c|c|c|c|c|}
\hline No & Interval Nilai & $\begin{array}{c}\text { Jumlah } \\
\text { Siswa }\end{array}$ & Presentase & $\begin{array}{c}\text { Kategori } \\
\text { Penilaian }\end{array}$ \\
\hline 1 & $90 \leq \mathrm{SKS}<100$ & 0 & $0 \%$ & Sangat Baik \\
\hline 2 & $75 \leq \mathrm{SKS}<90$ & 0 & $0 \%$ & Baik \\
\hline 3 & $65 \leq \mathrm{SKS}<75$ & 0 & $0 \%$ & Cukup \\
\hline 4 & $45 \leq \mathrm{SKS}<65$ & 13 & $43,33 \%$ & Kurang \\
\hline 5 & $0 \leq \mathrm{SKS}<45$ & 17 & $46,67 \%$ & Sangat Kurang \\
\hline
\end{tabular}

SKS: Skor Kemampuan Spasial 
Dari Tabel 2. terlihat pretes kemampuan spasial pada kelas eksperimen 1 diperoleh data bahwa jumlah siswa yang memperoleh nilai sangat kurang sebanyak 17 siswa atau sebesar 46,67\%, yang memiliki kategori kurang sebanyak 13 siswa atau sebesar 43,33\%, tidak ada yang memiliki kategori cukup, baik dan sangat baik. Selanjutnya untuk preteskemampuan spasial siswa pada kelas eksperimen 2 dapat dilihat pada Tabel 3.

Tabel 3. PretesKemampuan Spasial Siswa Dengan Metode Ekspositori Berbantuan Software Cabri $3 D$ (Kelas Eksperimen 2) Secara Kuantitatif

\begin{tabular}{|c|c|c|c|c|}
\hline No & Interval Nilai & $\begin{array}{c}\text { Jumlah } \\
\text { Siswa }\end{array}$ & Presentase & $\begin{array}{c}\text { Kategori } \\
\text { Penilaian }\end{array}$ \\
\hline 1 & $90 \leq \mathrm{SKS}<100$ & 0 & $0 \%$ & Sangat Baik \\
\hline 2 & $75 \leq \mathrm{SKS}<90$ & 0 & $0 \%$ & Baik \\
\hline 3 & $65 \leq \mathrm{SKS}<75$ & 0 & $0 \%$ & Cukup \\
\hline 4 & $45 \leq \mathrm{SKS}<65$ & 16 & $42,11 \%$ & Kurang \\
\hline 5 & $0 \leq \mathrm{SKS}<45$ & 22 & $57,89 \%$ & Sangat Kurang \\
\hline
\end{tabular}

SKS: Skor Kemampuan Spasial

Dari Tabel 3. terlihat kemampuan spasial pada kelas eksperimen 2 bahwa jumlah siswa yang kurang sebanyak 16 siswa atau sebesar $42,11 \%$, tidak ada siswa yang memiliki kategori cukup, tidak ada siswa yang memiliki kategori baik dan sangat baik.

\section{Postes Kemampuan Spasial}

Secara kuantitatif, tingkat postes pasial disajikan pada tabel 4.

Tabel 4. PostesSpasial Siswa Kelas Eksperimen 1 Secara Kuantitatif

\begin{tabular}{|l|c|c|c|c|}
\hline No & Interval Nilai & Jumlah Siswa & Presentase & Kategori Penilaian \\
\hline 1 & $90 \leq \mathrm{SKS}<100$ & 9 & $30 \%$ & Sangat Baik \\
\hline 2 & $75 \leq \mathrm{SKS}<90$ & 14 & $46,67 \%$ & Baik \\
\hline 3 & $65 \leq \mathrm{SKS}<75$ & 5 & $16,67 \%$ & Cukup \\
\hline 4 & $45 \leq \mathrm{SKS}<65$ & 2 & $6,67 \%$ & Kurang \\
\hline 5 & $0 \leq \mathrm{SKS}<45$ & 0 & $0 \%$ & Sangat Kurang \\
\hline
\end{tabular}

SKS: Skor Kemampuan Spasial

Dari Tabel 4. berdasarkan skor posteskemampuan spasial siswa pada kelas eksperimen 1 terlihat bahwa tidak ada siswa yang memperoleh nilai sangat kurang, yang memiliki kategori kurang sebanyak 2 siswa atau sebesar 6,67\%, yang memiliki kategori cukup 5 siswa atau sebesar 16,67\%, untuk kategori baiksebanyak 14 atau sebesar 46,67\% dan sangat baik sebanyak 9 siswa atau sebesar30\%. Selanjutnya untuk postes siswa spasial pada kelas eksperimen 2 disajikan pada Tabel 5 .

Tabel 5. PostesSpasial Siswa Kelas Eksperimen 2 Secara Kuantitatif

\begin{tabular}{|l|c|l|l|c|}
\hline No & Interval Nilai & $\begin{array}{l}\text { Jumlah } \\
\text { Siswa }\end{array}$ & Presentase & $\begin{array}{l}\text { Kategori } \\
\text { Penilaian }\end{array}$ \\
\hline 1 & $90 \leq \mathrm{SKS}<100$ & 0 & $0 \%$ & Sangat Baik \\
\hline 2 & $75 \leq \mathrm{SKS}<90$ & 20 & $52,63 \%$ & Baik \\
\hline 3 & $65 \leq \mathrm{SKS}<75$ & 6 & $15,79 \%$ & Cukup \\
\hline 4 & $45 \leq \mathrm{SKS}<65$ & 12 & $31,57 \%$ & Kurang \\
\hline 5 & $0 \leq \mathrm{SKS}<45$ & 0 & $0 \%$ & Sangat Kurang \\
\hline
\end{tabular}

SKS: Skor Kemampuan Spasial 
Dari Tabel 5. terlihat dari hasil postesspasial pada kelas eksperimen 2 diperoleh bahwa tidak ada siswa yang memperoleh nilai sangat kurang, yang memiliki kategori kurang sebanyak 12 siswa atau sebesar 31,57\%, yang memiliki kategori cukup sebanyak 6 siswa atau sebesar 15,57\%, untuk kategori baik sebanyak 20 siswa atau sebesar 52,63\% dan tidak ada siswa yang mendapatkan kategori sangat baik. Untuk memperjelas rekapitulasi data-data statistik tes postes antara kelas eksperimen 1 dengan kelas eksperimen 2 disajikan pada Tabel 6.

Tabel 6. Rekapitulasi Hasil PostesKemampuan Spasial Siswa

\begin{tabular}{|c|l|l|c|c|}
\hline \multirow{2}{*}{ Jenis Tes } & \multirow{2}{*}{ No } & \multicolumn{1}{|c|}{ Aspek } & \multicolumn{2}{|c|}{ Kelompok Pembelajaran } \\
\cline { 3 - 5 } & & & Eksperimen 1 & Eksperimen 2 \\
\hline \multirow{4}{*}{ Postes } & 1 & Rata-rata Postes & 84,64 & 75,188 \\
\cline { 2 - 5 } & 2 & Jumlah siswa yang tuntas & 27 & 29 \\
\cline { 2 - 5 } & 3 & Varians & 130,65 & 103,05 \\
\cline { 2 - 5 } & 4 & \% Ketuntasan & $90 \%$ & $76 \%$ \\
\hline
\end{tabular}

\section{Analisis Deskriptif Disposisi Matematik}

Tes disposisi matematik siswa dilakukan dua kali yaitu tes awal dan tes akhir. Tes awaldan tes akhir diikuti oleh 30 siswaeksperimen 1 dan 38 siswa eksperimen 2. Rata-rata skor tes siswa untuk kelas eksperimen 1 dan kelas eksperimen 2 dirangkum pada Tabel 7.

Tabel 7. Rekapitulasi Ketuntasan Hasil Disposisi Matematik Siswa

\begin{tabular}{|l|l|c|c|}
\hline \multirow{4}{*}{ Skala } & \multicolumn{2}{|c|}{ Aspek } & \multicolumn{2}{|c|}{ Kelompok } \\
\cline { 3 - 4 } & & Eksperimen 2 & Eksperimen 1 \\
\hline \multirow{4}{*}{$\begin{array}{l}\text { Disposisi } \\
\text { matematik }\end{array}$} & Rata-rata skor awal & 62,50 & 63,37 \\
\cline { 2 - 4 } \begin{tabular}{l} 
Siswa \\
\cline { 2 - 4 }
\end{tabular} & Rata-rata skor akhir & 80,00 & 89,53 \\
\cline { 2 - 4 } & NRS skor awal & 2,08 & 2,23 \\
\cline { 2 - 4 } & NRS skor akhir & 2,67 & 3,03 \\
\cline { 2 - 4 } & \% NRS skor awal & 45 & 64,51 \\
\cline { 2 - 4 } & \% NRS skor akhir & 56,58 & 60,62 \\
\hline
\end{tabular}

Pada Tabel 7. dapat dilihat disposisi matematik siswa, rata-rata skor awal dan akhirsiswa kelas eksperimen 2 adalah 62,50 dan 80,00. Bila diperhatikan rata-rata skor kelas eksperimen 2 terjadi perbedaan rata-rata skor sebesar 22,5. Sedangkan kelas eksperimen 1 yaitu 63,37 dan 89,53 terjadi perbedaan rata-rata skor sebesar 26,16. Selisih skor awal dan akhir kelas eksperimen 1 lebih besar dari selisih skor awal dan akhir kelas eksperimen 2. Untuk mengetahui perbedaan disposisi matematik siswa tiap peserta didik terhadap mata pelajaran, dilihat dari jumlah skor individu. Dimana NRS skor awal dan skor akhir di kelas eksperimen 2 adalah 2,08 dan 2,67, lanjut dengan NRS skor awal dan skor akhir di kelas eksperimen 1 adalah 2,23 dan 3,03, Sedangkan untuk mengetahui persentase perbedaan disposisi matematik siswa kelas dilakukan dengan cara menentukan rata-rata skor siswa dibagi dengan jumlah skor total dikali 100\%. Untuk skor awal dan akhir di kelas eksperimen 1 menghasilkan 55,51\% dan 60,62\% dan di kelas eksperimen 2 menghasilkan 45\% dan 56,58\%. 
Berdasarkan hasil skor awal dan akhir yang diberikan sebelum dan sesudah pembelajaran di kelas eksperimen 1 maupun eksperimen 2. Rata-rata skor awal kedua kelas terdapat perbedaan sebesar 0,87. Hal ini menunjukkan bahwa rata-rata skor awal untuk kedua kelas relatif sama, oleh karena itu masing-masing kelas boleh mendapatkan perlakuan yang berbeda. Jika terjadi perbedaan kemampuan siswa pada akhir proses pembelajaran, maka perbedaan tersebut dapat dilihat sebagai akibat adanya perlakuan yang berbeda pada kedua kelas tersebut.

\section{Diskusi}

Pembahasan hasil penelitian berikut ini akan diuraikan deskripsi dan interpretasi terhadap kemampuan spasial dan disposisi matematik dalam menyelesaikan masalah yang diberikan pada pendekatan penemuan terbimbing berbantuan Software Cabri 3D dan metode ekspositori berbantuan Software Cabri 3D.

\section{Faktor Kemampuan Spasial}

Berdasarkan hasil pretes kemampuan spasial matematik dari kelas ekperimen 1 terdapat 13 orang dalam kelompok kategori kurang dan 17 orang dalam kategori sangat kurang. Sedangkan pada kelas eksperimen 2 terdapat 16 orang dalam kelompok kategori kurang dan 22 orang dalam kategori sangat kurang.Postes kelas eksperimen 1 terdapat sebanyak 2 orang dalam kelompok kategori kurang, 5 orang dalam kelompok kategori cukup, 14 orang dalam kelompok kategori baik dan 9 orang dalam kelompok sangat baik. Selanjutnya untuk postes spasial pada kelas eksperimen 2 terdapat sebanyak 12 orang dalam kelompok kategori kurang dan 6 orang dalam kelompok kategori cukup dan 20 orang dalam kategori baik.

Hasil penelitian menunjukkan tidak adanya kepastian peningkatan jumlah siswa antar tinggi, sedang dan rendah baik pada kelas eksperimen 1 maupun kelas eksperimen 2.Hal ini mengindikasikan tidak adanya peningkatan dan penurunan yang konstan.Kemudian hal ini juga mengindikasikan keragaman hasil tes siswa baik pada pretes maupun postes. Namun dari segi ketuntasan, terdapat hasil yang sangat signifikan, dimana pada postes ketuntasan siswa mencapai $27 \%$ pada eksperimen 1 dan 76\% pada eksperimen 2. Hal ini mengindikasikan pembelajaran dengan pendekatan penemuan terbimbing berbantuan Software Cabri 3D dan metode ekspositori berbantuan Software Cabri 3D memberikan pengalaman belajar yang sangat berarti sehingga mayoritas siswa dapat tuntas.Selain itu, kedua model pembelajaran ini memberikan hasil yang berbeda, diuji dari statistik inferensialnya. Hal ini senada dengan hasil studi yang dilakukan Dinda Putri Rezeki (Rezeki, 2012) terhadap siswa kelas VII Semester II di SMPN 1 Stabat menunjukkan adanya perbedaaan kemampuan spasial dan kemampuan pemecahan masalah yang diajar melalui pendekatan penemuan terbimbing dengan pembelajaran konvensional.

\section{Faktor Disposisi Matematik}

Disposisi siswa dapat diartikan sebagai belajar aktif, yang didorong oleh niat atau motif untuk menguasai suatu kompetensi guna mengatasi suatu masalah, dan dapat dibangun dengan bekal pengetahuan atau kompetensi yang telah dimiliki, serta dapat menumbuhkan rasa percaya diri yang 
proporsional keyakinan atau kepercayaan individu untuk mengorganisasi suatu tugas mencapai suatu tujuan, menghasilkan sesuatu dan mengimplementasi tindakan maka individu harus memulainya dari dalam diri sendiri. Hal ini sangat penting mengingat bahwa hanya individu yang bersangkutan yang dapat mengatasi rasa kurang percaya diri yang sedang dialaminya.

Berdasarkan hasil analisis data penelitian,perbedaan disposisi siswa yang diajar melalui pembelajaran dengan pendekatan penemuan terbimbing berbantuan Software Cabri 3D lebih tinggi daripada peningkatan disposisi siswa yang diajar melalui pembelajaran dengan metode ekspositori berbantuan Software Cabri 3D. Tingginya perbedaan disposisi siswa pada pembelajaran dengan pendekatan penemuan terbimbing berbantuan Software Cabri $3 D$ disebabkan pembelajaran dengan pendekatan penemuan terbimbing berbantuan Software Cabri $3 D$ dapat membuat siswa mengalami menemukan konsep-konsep matematika yang diberikan sehingga rasa percaya diri akan kemampuan yang dimiliki semakin meningkat pula.

Studi yang dilakukan Nur Izzati (Izzati, 2012) yang berjudul Peningkatan kemampuan komunikasi matematis dan disposisi siswa SMP melalui pendekatan penemuan terbimbing.Penelitian ini bertujuan untuk mengetahui seberapa besar kontribusi penerapan pendekatan penemuan terbimbing terhadap perbedaankemampuan komunikasi matematis dan disposisi siswa dalam matematika. Hasil penelitian ini menunjukkan bahwa bahwa KKM siswa yang mendapat pembelajaran matematika melalui pendekatan penemuan terbimbing lebih tinggi secara signifikan dibanding dengan siswa yang mendapat pembelajaran dengan model pembelajaran biasa.

Adapun hasil analisis statistik yang dilakukan dengan uji statistik menggunakan nonparametrik Mann Whitney dengan bantuan SPSS 16.00 untuk kelas eksperimen 1 dan kelas eksperimen 2 diperoleh nilai sig $<\alpha=0,05$, data tersebut menunjukkan bahwa rata-rata perbedaan disposisi siswa yang diberi pembelajaran dengan pendekatan penemuan terbimbingberbantuan Software Cabri 3Dlebih tinggi daripada rata-rata perbedaan disposisi siswa yang diberi metode ekspositori berbantuan Software Cabri 3D.

\section{KESIMPULAN}

1. Terdapat perbedaan yang signifikan antara kemampuan spasial matematik siswa yang diajar melalui pendekatan penemuan terbimbing berbantuan Software Cabri 3D dengan siswa yang diajar melalui metode ekspositori berbantuan Software Cabri 3D. Dimana terjadi peningkatan yang lebih tinggi pada kemampuan spasial matematik siswa yang diajar melalui pendekatan penemuan terbimbing berbantuan Software Cabri 3D.

2. Terdapat perbedaan yang signifikan antara disposisi matematik siswa yang diajar melaluipendekatan penemuan terbimbing berbantuan Software Cabri 3D dengan siswa yang diajar melalui metode ekspositori berbantuan Software Cabri 3D. Dimana terjadi peningkatan yang lebih tinggi pada disposisi matematik siswa yang diajar melalui pendekatan penemuan terbimbing berbantuan Software Cabri 3D. 


\section{UCAPAN TERIMA KASIH}

Terima kasih saya ucapkan kepada dosen pembimbing Bapak Mangaratua M Simanjorang, M.Pd, Ph.D. dan Bapak Dr. Mulyono, M.Si. Terima kasih juga saya ucapkan untuk semua pihak yang membantu dalam menyelesaikan penelitian ini.

\section{REFERENSI}

Depdiknas. (2013). Panduan Pengembangan Materi Pembelajaran. Direktorat Jendral Manajemen Pendidikan Dasar dan Menengah.

Hamzah, A., \& Muhlisrarini. (2014). Perencanaan dan Strategi Pembelajaran Matematika. Raja Grafindo Persada.

Izzati, N. (2012). Peningkatan Kemampuan Komunikasi Matematis dan Kemandirian Belajar Siswa SMP Melalui Pendekatan Pendidikan Matematika Realistik. Universitas Pendidikan Indonesia.

Kemendikbud. (2012). Panduan Integrasi Pendidikan Karakter dalam Pembelajaran IPA di Sekolah Dasar.

Kuhlthau, \& Todd. (2007). Guided Inquiry: A framework for learning through school librariesin 21st century schools. CISSL.

NCTM. (2013). A brief history and reflection. The National Council of Teachers of Mathematics, Inc

Rezeki, D. P. (2012). Analisis Perbedaan Kemampuan Berpikir Kreatif dan Pemecahan Masalah Matematik Antara Siswa yang Diberi Pembelajaran Open-Ended Dengan Pembelajaran Konvensional. UNIMED.

Sholihah, S. Z., \& Afriansyah, E. A. (2018). Analisis Kesulitan Siswa dalam Proses Pemecahan Masalah Geometri Berdasarkan Tahapan Berpikir Van Hiele. Mosharafa: Jurnal Pendidikan Matematika, 6(2), 287-298. https://doi.org/10.31980/mosharafa.v6i2.317

Slameto. (2010). Belajar dan Faktor - Faktor yang Mempengaruhi. Rineka Cipta.

Syarah, F. (2013). Peningkatan Kemampuan Spasial Dan Komunikasi Matematis Siswa SMP Melalui Pembelajaran Berbasis Masalah. Universitas Negeri Medan.

Tambunan, S. M. (2006). Hubungan Antara Kemampuan Spasial Dengan Prestas Belajar Matematika. Makara Sosial Humaniora, 10(1), 27-32. doi:10.7454/mssh.v10i1.13

Trianto. (2011). Mendesain Model Pembelajaran Inovatif - Progresif. Prestasi Pustaka. 